\title{
Congo: \\ Nonviolent Struggle in the DRC. Making Sense of the Consent Theory of Power
}

\author{
Jean-Marie Kasonga MBOMBO
}

\begin{abstract}
The history of the Democratic Republic of Congo (DRC) is awash with resistance against systemic exploitation of the country's huge mineral resources by foreign powers, coupled with repression of local population by subsequent regimes. This paper seeks to address the question as to why public withdrawal of consent does not necessarily cause the change of political power in line with the aspirations of the vast majority of citizens. The case study adopts an argumentative approach based on secondary data. The study reveals that the consent of the suffering masses is meaningless as far as regime change is concerned. In other words the survival of repressive regimes is contingent upon the submission of a co-opted few around the seat of power, the cooperation of hired agents of violence and the support of powerful multinationals that have vested interests in the status quo. In the light of Agency theory, it is argued that the success of nonviolent struggle against unpopular regimes depends on the astuteness of unarmed demonstrators to reach out to the agents of legitimate violence with an olive branch so as to not only bridge the distance between them but also turn them into partners for change. As a way forward, the study recommended a broad understanding of the concept of Civil-Military Relations that goes beyond elite framing.
\end{abstract}

Keywords: Power, Consent, Repression, DRC, Agents of violence, Shirk, Regime change.

Jean-Marie Kasonga MBOMBO

Centre for Peace and Strategic Studies

University of llorin, Nigeria

Email: jm.mbombo@yahoo.com

Conflict Studies Quarterly

Issue 25, October 2018, pp. 49-67

DOI:10.24193/csq.25.3

Published First Online: 05/10/2018

\section{Introduction}

Since the end of the Cold War, a few countries in sub-Saharan Africa have made progress in terms of political alternation by peaceful means. Others continue to experience political stagnation through rigged elections, co-option of key figures of the opposition and even indefinite postponement of electoral processes. As a result, political rallies and street protests have become daily occurrence but each time they are met with clinched fists of heavily-armed security 
men. Having lost confidence in their leaders, the majority of citizens stand by and wait for Divine intervention while a great deal of young people find enough reasons to brave the harshness of the Sahara desert and the turbulence of the open Sea in an attempt to escape the limitations imposed on them by their respective political leaders. Still, many more other youngsters turn to churches and mosques for spiritual breakthrough but end up as brainwashed radicals. This paper is concerned with the change of political power through nonviolent struggle in the Democratic Republic of Congo. It adopts a case study approach based on secondary data and seeks to address the question as to why the withdrawal of consent through peaceful means does not necessarily translate into regime change. The study submits that power shift in authoritarian regimes is contingent upon the ability of nonviolent activists to offer an olive branch to the agents of violence that are closer to them and seek their conversion (defection) rather than trying to reach out to the dictator who lives in a fortified castle.

\section{Consent theory of power}

Power has been associated with force, authority and influence (Evans \& Newnham, 1998). It can be monolithic and pluralistic. Every state government retains the monopoly of violence and compels the citizenry to obey the laws of the land willy-nilly. Monolithic power is therefore reserved exclusively to the ruler and it comes from the barrel of a gun as long as armies and police forces are stationed around the seat of power to protect incumbents. On the other hand, a pluralistic power is a kind of support given to the ruler through the acquiescence and cooperation of various actors within a particular system. As Atack (2012) contends, such power springs "from the diverse social groups that make up the base of any social and political hierarchy, through this relationship of consent and compliance" (p. 12). The power of consent is central to nonviolent struggle construed as "a technique used to control, combat and destroy the opponent's power by nonviolent means of wielding power" (Sharp, 1973, p. 4). This study relies on Gene Sharp's definition of pluralistic power as "the total authority, influence, pressure and coercion which may be applied to achieve or prevent the implementation of the wishes of the power-holder" (Sharp, 1973, p. 8; 2012b, p. 229).

Many activists and scholars have written extensively about the relevance of nonviolent action towards regime change (Chenoweth \& Cunningham, 2013; Nepstad, 2013) but as Brian (1989) observes, it was Gene Sharp who developed the consent theory of power: citizens of any nation provide political power to the ruler through voluntary obedience and cooperation and they can as well overcome repression by withdrawing their support to the regime. The power-through-consent actually gives power to the ruler and it is more apparent in democratic societies. As a bargaining chip, it takes the form of negotiation between the people and the government so much so that it is difficult to know who is actually in charge. Whereas the elected elite believe that the people's vote implies a transfer of power from bottom up, the electorate clings to their 
voting rights and presses for the rule of law, transparency and accountability. Even though it makes sense to link democracy and consent as opposed to dictatorship and cadaveric obedience, it is important to bear in mind that the survival of regimes in both democratic and non-democratic systems depends on several sources of power (Sharp, 1973). The scholar identifies six sources of power stemming from the cooperation of the citizenry as follows:

1. Shared belief among the people that the regime is legitimate and worthy of obedience;

2. Assistance to the ruler by the commitment of individuals and groups (human resources);

3. Supply of skills and knowledge through the cooperation of the peoples;

4. Psychological and ideological factors which may induce the masses to obey and assist the rulers;

5. Ruler's access to and control over material resources such as mineral wealth, financial resources, means of communication and transportation;

6. Sanctions, punishments, threatened or applied, to ensure the submission and cooperation that are needed for the regime to carry out its policies and to exist (Sharp, 2012a; 2012b).

Schock (2013) associates the power of consent in civil resistance with a lever through which oppressed people can defeat repressive opponents through collective actions intended to drain the legitimacy to rule by withdrawing every support as opposed to a hammer that engages direct force upon them through armed movements. However, the elite in power constantly try to defuse the power of the citizenry, sometimes using the hammer, so that saying nothing equates with consenting. This begs the question as to how different sources of power avail themselves simultaneously in order to either support the ruler or withdraw their cooperation in an attempt to bring down the system altogether. Atack (2012) devises the pluralistic power as a combination of three types, reflecting a hierarchical structure of every society: the power over, available to the ruling elite that occupies the top level (the ruler and closest collaborators), followed by the power with, that rests with governing institutions (army, police and civil servants) and stemming from the cooperation of these institutions towards agreed goals. At the bottom of the pyramid is found the power of consent, compliance and obedience in the hands of the vast majority of the population. The merit of this model is twofold: the withdrawal of consent does not imply the change of the regime on top and the power of the ruler depends on the cooperation of the governing institutions in the middle of the pyramid. Put simply, the grassroots' initiative (withdrawal of consent) must target key institutions upon which the power of the ruler is based before any change of can occur. By acting without the consent of the people, the elites in power actually usurp and lose their legitimacy to govern. However, when citizens forfeit their freedom as a result of 
state repression, they lose their political leverage. Cadaveric obedience becomes the only currency available to those who want to trade with the powerful, except for the few who are not ready to sell their birthright. Therefore, in order to undermine the system that has been run without their consent (explicit or latent), activists may engage in acts of civil disobedience by refusing to do what they have been forced to do or forbidden to do (Sharp, 2005). Protest begins at the bottom of the pyramid by the same people who were at the polling station yesterday. They are calling on the attention of their representatives over particular issues of mutual interests. They do not constitute a political party whose ambition is about taking over power. They rather identify their opponent and seek the conversion of the latter (Sharp, 2005). Contrary to transnational terrorist movements that launch indiscriminate attacks in secret and cause untold damage to innocent life, nonviolent protesters have a clear agenda in mind, which is not hidden from the general public. They belong to the civil society and operate in the open, with the intention of reaching out to a wider audience: "Openness will facilitate (but not ensure) the opponents' understanding of the nonviolent struggle group's motives, aims, intentions and plans" (Sharp, 2005, p. 370). Such actions involve organizing, training and disciplining large masses of people (Nojeim, 2004).

The training revolves around the use of selected techniques, which Gene Sharp has brought down to three categories, namely protest and persuasion, noncooperation and nonviolent intervention (Sharp, 2012b). It is unwise to stop cooperation without having publicly expressed one's dissatisfaction. According to Zunes, Kurtz and Asher (1999), the technique of protest and persuasion means that "we name what we think is wrong, point out fingers at it and try to help others understand" (p. 21). This is absolutely the right of every citizen in a democratic society. No wonder that techniques such as petitioning, picketing, demonstrating, and lobbying are daily occurrence in places where people enjoy freedom of expression. Usually, peaceful demonstrations in democratic societies have the advantage of attracting Media's coverage as well as the service of the Police to ensure the safety of protesters. This brings home the message that policy-makers are in the know. The next thing to do for the protesters is to wait and see what will happen next. At this first stage, they expect the other party (government) to have a change of heart (conversion). The aim of the protest is to call on the goodwill of the ruling elite to live up to expectations. If nothing is forthcoming, protesters resume the struggle with different techniques under the category of noncooperation: boycotts, strikes, tax resistance and the like.

Noncooperation means that "we deliberately fold our hands and turn our backs, refusing to participate in the wrong we have named" (Zunes et al., 1999, p. 21). Noncooperation affects both the government and the people at different levels. At least, it shows that both camps depend on each other for survival. They must reach some compromise (accommodation) before the trouble goes out of hand. So far, the people's action has been indirect and somehow ineffective. The struggle intensifies only when the parties 
involved fail to negotiate. It is then that nonviolent intervention becomes direct action with techniques designed to interfere, to block the smooth running of the system such as physical obstruction, civil disobedience, sit-ins, parallel institutions and the like. It is worth mentioning that these techniques are sequential steps in nonviolent struggle in the sense that one causes the other. Should the government heed the message of the marchers in the first place and change its policy accordingly, nonviolent action would stop at the level of protest and persuasion. The next section of the study makes reference to some classic examples of nonviolent struggle to highlight the power of consent in practice.

\section{Nonviolent struggle in practice: Gandhi, King and the People's Power}

Mahatma Gandhi had his life transformed in the face of massive injustices in South Africa over the issues of segregation, Indian Franchise Bill, exorbitant taxation. The brutality he and the people of colours suffered under both the apartheid regime in South Africa and the colonial rule in his native land (India) convinced him that the British authorities were not living up to their professed ideals (Schell, 2004). He also discovered that constitutional pressures, petitions, and rational persuasion would make little or no impact on 'prejudiced' minds. So, he challenged his fellows to first liberate themselves from fear in order to rediscover the immense force within. As Parekh (1997) puts it, "he urged them to 'rebel' against themselves, and warned them that those who behave like worms should not blame others for trampling upon them" (p. 9). Against what he describes as 'passive resistance', Gandhi adopted a strategy known as satyagraha, an experiment with the truth, a search for truth both within and in the other (Schell, 2004).

This strategy aimed at one goal: shaming rather than destroying the opponent, with the possibility of reaching a dialogue. It was meant to expose the power base of the ruler in every context: "I believe and everybody must grant that no Government can exist for a single moment without the cooperation of the people, willing or forced, and if people withdraw their cooperation in every detail, the Government will come to a standstill" (Schell, 2004, p. 129). It is worth noting that the pluralistic sources that supplied the British with the power to rule were within India. That is why Gandhi targeted colonial institutions. In other words, he urged his countrymen to boycott British goods as demonstrated in the famous Salt March in 1930, resign from government employment and forsake British titles and honours for the purpose of crippling the colonial government economically, politically and administratively. For him, the final arbiter was not military might but the consent, and the cooperation that flowed from it (Parekh, 1997). Once the colonized people were able to muster all their strength and withdraw their cooperation, the British power to lord it over India crumbled.

Reverend Martin Luther King Jnr developed his philosophy of nonviolent struggle after he had been chosen to lead the Montgomery bus boycott (1955) in Alabama. He used it 
as a tactic to win the Civil Rights for the Black Community. The Civil Rights Movement under the leadership of King was based on the love of one's enemy preached by Jesus, studied by Tolstoy and practiced by Gandhi. As Nojeim (2004) points out, "He [King] liked to say that Christ furnished the spirit and Gandhi provided the technique for his nonviolent approach to racial injustice" (p. 184). He captured the issue of racial discrimination as a political arrangement in which everybody was caught up in the quagmire of dehumanization: both the repressive government and the marginalized Black people needed to reclaim their lost humanity. He specifically challenged the Black folk to replace the use of violence with non-cooperation. According to Powers, Vogele, Kruegler and McCarthy (1997), "King posited that through nonviolence, African Americans could end racial oppression, free themselves and their white oppressors from the sin of racial discrimination and then build a beloved community based on equality and Christian love" (p. 90).

Likewise his mentor Gandhi, Rev. King had a clear idea of who the opponent were and how to face them. He knew that it was counterproductive to use violent means against a government that held superior power to crush its opponents (Sharp, 2012a). Accordingly, he led nonviolent civil disobedience with the purpose of stirring up tension which would in the end compel the US government to open the doors to negotiations:

We shall match your capacity to inflict suffering by our capacity to endure suffering... One day we shall win freedom, but not only for ourselves. We shall so appeal to your heart and conscience that we shall win you in the process and our victory will be a double victory" (Powers et al., 1997, p. 291).

It is important to observe however that the Civil Rights Movement which was sparked by Rosa Parks' bus boycott on December 1, 1955 targeted the transport sector of the US economy. Activists also lobbied and worked with Congress as a key institution in the US to overturn discriminatory legislation instead of calling on the resignation of the President. Thanks to the media coverage, the Birmingham demonstration (1963) exposed to the whole world the paradox of American society that disenfranchised a portion of her population while standing for the equality of all people as stated in the Universal Declaration of Human Rights (1948). Through King-led civil disobedience, the consent power was apparent in the withdrawal of cooperation by the Black community and a great deal of White sympathizers against the systemic racial discrimination. At the end of a long walk for equality, the Johnson-led administration adopted the landmark Civil Rights Act of 1964 which ended de jure segregation in the United States.

The Filipino saga is perhaps the best illustration of the consent power whose withdrawal resulted in the disintegration of the Marcos' rule (Sharp, 2012b; Zunes et al., 1999). What triggered the People's Power in the Philippines in 1986 is arguably the ballot power. The concept of 'People's power' literally means democracy in which the people exercise their power through elected representatives. It all began when President 
Marcos decided to perform the ballot ritual in order to legitimize his autocratic rule. Convinced that the elections had been rigged, the opposition party led by Cory Aquino called for mass protests. Without delay, a coalition of three sections of the population responded with different motives: politicians, mutineers, and civilians. The most striking point in this struggle was that the people held the keys to the success of the crisis. Although the conflict had been masterminded by the opposition party in connivance with the rebel leaders, the unarmed civilians interposed themselves between loyalists and rebel troops in order to preempt a violent outcome. They facilitated the resolution of the conflict by extending their love and friendship towards both camps. However, far from being a spontaneous mass uprising, the success of nonviolent struggle in Manila was a culmination of years of preparation and training in nonviolent techniques (Zunes et al., 1999). It came at the right time when external players had decided to withdraw their logistic supports to the regime. Not only did the nonviolent activists melt the hearts of armed men, they also facilitated the coalition of loyalists and mutineers against the regime and within 77 hours, the incumbent lost the legitimacy to rule (Nepstad, 2013).

Everything considered, nonviolent struggle was for Gandhi and King a way of life geared toward reconciliation with one's opponent (Atack, 2012). These two figures enjoyed vested authority as charismatic leaders. However, the People's Power stands out as a demonstration of the power of consent in which different sources of power conflated and produced a regime change. By way of drawing a parallelism, the next section considers a case study that deals with the question as to why the withdrawal of consent at the bottom of the pyramid is far from causing the downfall of the Kabila regime.

\section{Case study: Democratic Republic of Congo}

Located in Central Africa, the DRC spans a surface area of 2.3 million square kilometers of which arable land covers 80 million of hectares. It is sometimes described as a geological scandal given its abundant natural resources (over 1,100 minerals and precious metals) that have the potential to make it into one of the richest countries in the world (World Bank, 2015). However, the country remains one of the poorest on the planet, occupying the $176^{\text {th }}$ position out of 187 (UNDP, 2015). It is also placed in the category of "Not free" states, with worst scores for freedom, civil liberties and political rights (Freedom House, 2013). How have the people of Congo resisted wholesale repression with its attendant pauperism over the years? In an attempt to justify the proneness of violent conflicts in mineral-rich countries, particularly in post-colonial Africa, resourcecurse theorists establish a link between natural wealth and civil wars, laying emphasis on the greed of local warlords (Collier and Hoeffler, 2004; Collier and Sambanis, 2005; Moss, 2007). They, nevertheless, stop short of unveiling another important link between local entrepreneurs of conflict and multinational conglomerates according to the basic law of supply and demand. In other words, it is not enough to focus our attention on the greed/grievance of the supplier of blood minerals and fail to expose the growing 
appetite of the hungry demander that sustains the war economy. A synoptic account of a long history of oppression can be divided into five regimes which have in common the dominant interests of powerful actors against the emergence of a strong, stable and legitimate leadership in the DRC.

To begin with, King Leopold II of Belgium set up a NGO (the first of its kind) called the International Association of the Congo from the luxury of his palace at Laeken in Brussels in 1876. Though absent at the West Africa Conference in Berlin (1884-1885), he was assigned the control of what became known as 'Congo Free State' (CFS) with a specific mission of establishing a free trade zone in which different companies would come and exploit available resources hitch-free (Pakenham, 1991, p. 249). Under the command of British explorer Henry M. Stanley, the King's private army, La Force Publique (FP), became notorious in the art of flogging, severing of hands and rationing food supply as modes of punishment against resisters (Cordell, Wiese, Payanzo and Marchand, 2018). FP was also famous in burning down entire villages and slaughtering those who attempted to rebel against the system. These agents of terror would kidnap wives and children of fugitives and forced the latter to surrender and meet unrealistic work quotas before securing the release of their loved ones (Nzongala-Ntalaja, 2015). In short, the King's project of making blood money out of rubber and ivory was a renewed form of slavery on the African soil that caused a rapid depopulation of indigenes estimated around 10 million deaths (Quinn, 2005; Snow, 2007). More important, it left behind a terrorized population with a high degree of 'colonizability' (compliance).

Inhuman treatment inflicted upon the natives by Leopold's agents attracted international condemnation and as a result, the Belgian government decided to whitewash the King's crime against humanity by taking over the CFS in 1908. But the speed of repression meted out to traumatized populations entered a higher gear as a result of high demand of raw materials in the aftermath of World War I and II. Colonial policies of hard labor were designed to prevent the emergence of local leadership because 'no elite implies no trouble'. Accordingly, the education system was kept in check, below the secondary level so as to keep the natives infantile and submissive throughout the colonial era. As Cordell et al. (2018) contend, Belgian paternalism was an irreducible tendency to treat Africans as children with a firm commitment to political control and compulsion, which ruled out initiatives designed to foster political experience and responsibility. However, voluntary compliance with state regulations was not the case, particularly in the rural areas where peasant resistance to colonial rule took on both violent and nonviolent forms (Nzongala-Ntalaja, 2015, p. 25).

After five days of Independence (June 30,1960), the Congo descended into chaos after departing officers instigated a mutiny within the national army. The ensuing riot gave Brussels the pretext to deploy its troops in her former colony for the protection of foreign nationals. The newly elected head of government Patrice E. Lumumba, 
who was constantly arrested by the colonial authority for civil disobedience, was dismissed from premiership in a bloodless coup by the Army chief of Staff, Joseph Mobutu on 14 September 1960 and murdered four months later under the watch of the UN Peacekeeping troops. Following in the footsteps of King Leopold II, Mr. Mobutu's rule relied strongly on the support of Western powers. As Nzongala-Ntalaja (2015) contends, external players looked for "a ruler who had no social base or constituency to which he could be accountable nationally, so he could be expected to fully implement the policies dictated to him from abroad" (p. 27). At home, the client regime that lasted 32 years was famous in the art of rewarding loyalists with political portfolios (cooption) while repressing dissenters. Foreign troops and mercenaries were readily available to shore it up by fighting insurrection and crushing down peaceful demonstrations. Needless to say that the withdrawal of Western support at the end of the Cold War culminated in the downfall of the Mobutu rule without the involvement of local actors in May 1997.

Heading the Alliance of Democratic Forces for the Liberation (AFDL), the self-proclaimed President Laurent Desire Kabila had his regime shortened when he failed to meet the expectations of his foreign allies. The latter only needed another Stanley-like figure on the ground to facilitate the exploitation of the Congo's natural resources and a nationalist figure was not the right choice (Snow, 2007). Once again, it was not the consent power of the masses that pulled the plug for a regime change to occur despite civil resistance against occupying forces but the fall of Laurent Desire Kabila on 16 January 2001 in the course of fighting the war of aggression by unknown assassins. The 'African World War' involving many African countries testified to the influence of foreign powers in the DRC between 1996 and 2003 (Prunier, 2009). The then UN Secretary General Boutros-Ghali describes the Congo tragedy as "a new Anglo-American conflict which France, and the Anglo-American block won through Uganda and Rwanda" (Philpot, 2005, p. 101). By the time various troops were forced to pull out, they left behind proxy armed groups to securitize the mines on behalf of global players and terrorize local populations to date, especially in eastern Congo.

Unknown to the public and aged 29, Joseph Kabila succeeded his slain father as if Congo was a monarchy. It is worth noting briefly that UN Peacekeeping troops were deployed to stabilize the war-torn country. They actually paved the way for international financial institutions (the World Bank, International Monetary Fund) and other UN sister agencies to resume their activities in the capital Kinshasa. The Global and All-Inclusive Accord for the transition - Accord Global Inclusif (AGI) was signed in Pretoria under the watch of the government of South Africa and it recognized the incumbent as Transition President who would share political power with four vice-presidents on April 7, 2003. An international committee to oversee the transition at the level of ambassadors accredited in DRC, known by its French acronym - CIAT (Comite International d'Accompagnement de la Transition) was also launched and it facilitated the drafting of a new Constitution 
which was finally promulgated in 2006 after a Yes vote in a referendum a few months earlier. As if that was not enough, the European Force (EUFOR) was called upon to securitize the ballots in Kinshasa while the Blue Helmets policed the countryside before the incumbent could emerge winner of the presidential elections in December 2006. Arguably, the election of Joseph Kabila was a victory in a pre-emptive war stemming from the cooperation of the UN and the EUFOR against the interests of the Congolese electorate (Mbombo, 2008). Since then, members of the opposition have been atomized, that is turned into masses of isolated individuals that are incapable of working together to achieve regime change.

The hope for a peaceful change of regime was dashed when the incumbent modified the Electoral Law in 2011 and thereafter won for the second time the elections in a simple majority vote against ten other contestants. Toward the end of his second and last term in office, the taciturn president decided to remain in power by hook or crook. He invited the opposition parties to a roundtable dialogue which was endorsed by the international community with the intention of co-opting some key members of the opposition and gerrymandering others. The inconclusive dialogue was then followed by another series of talks, facilitated by the prelates that eventually produced on 30 December 2016 the Saint Sylvester Accord in which parties agreed to the organization of presidential elections within a year, to be followed by a peaceful change of regime (Mbombo, 2017). However, the nature of the repressive rule was once again displayed by the brutality of security forces in their attempt to prevent a peaceful march of Christians, calling for the implementation of the 2016 Accord on the New Year Eve. As Sharp (2012a) argues, "Dictators are not in the business of allowing elections that could remove them from their thrones" (p. 9). Given that obedience as an internal source of power has been publicly withdrawn on 31 December 2017, it becomes obvious that the Kabila regime that has lost its constitutional legitimacy to rule now relies heavily on the caprice of external forces. As Schock (2013) contends, "governments depend on the cooperation of their own citizens, but also on other states and, increasingly, non-state transnational entities" (p. 284). The next section of the study discusses the challenges of power shift against the interests of external supporters.

\section{Back to basics: why reliance on citizen's consent is not enough}

Critiques of Sharp's pluralistic power argue that the model is associated with the voluntaristic behavior of individuals in the society and it does not pay much attention to many factors such as patriarchy, capitalism, or the impact of a given educational system (Brian, 1989, 1999; Burrowes 1996). Similarly, the consent theory is unsatisfactory because it fails to analyze the structural roots of power in society: "People's obedience to rulers is not so much an element of free personal choice that can be reversed at will, but a characteristic of the way society is organized" (Danjani, 1994 as cited in Zunes, Merriman and Stephan, 2010). In the absence of free choice, there seems to be no room 
for consent especially when power relation remains unbalanced. More important, the pluralistic model of power focuses on internal sources of power and overlooks the impact of external actors. Sobek and Clare (2013) argue that this reliance on internal sources of power misses an important power resource available to a state, namely its external relations. As they put it: "it is reasonable to expect that when a state estimates the power of a potential opponent it looks not only at the internal resources but also at the power of states that would likely join the conflict" (p. 477). Therefore, internal and external sources of power must be considered if we want to explain the failure of nonviolent action towards regime change (Nepstad, 2013).

The flattened world that followed the end of the Cold War (Friedman, 2006) has caused most state governments in the southern hemisphere to share their powers with a plethora of actors both local and foreign under the mantra of global governance (Duffield, 2001). As a result, the consent power in the hands of the citizenry has been diluted by foreign influence. International financial institutions, multinational corporations and mercenaries constitute a reliable power base for the survival of longstanding dictators. External influence targets two sides of the aisle discriminately, namely the people and the ruler. On the one hand, active citizens count on the help of virtual activists across international borders in their struggle for change through social media. The growing in number of demonstrators that thronged central districts in Tunisia, Cairo or Ouagadougou testifies to the overt support given to street protests in defiance of the government of the day. Together they publicly withdraw their cooperation (consent) and engage in civil disobedience until some degree of change is recorded. On the other hand, the backing of the ruling party by its numerous beneficiaries takes place behind closed doors. The main players are multinational corporations which dominate the mining, forestry and oil sectors (Batware, 2011). These global citizens are more powerful than many poor nations (Korten, 2001). They prefer the status quo to change because a known evil is better than unknown angel. In short, the presence of multinationals in a conflict-torn country sends a strong message of support to the ruling elite. Elworthy and Hayman (2005) expose the role played by Western multinational corporations to undermine local efforts towards change in strong terms:

They give bribes, inducements or incentives to local politicians...do deals on natural resources, such as the European Union's purchase of fishing rights from Guinea Bissau, which take resources out of the hands of local people and channel them to the government.

In the DRC, external support to activists has produced a coalition of 14 international and close to 200 Congolese Rights Organisations, based in the troubled Kivu region. Popularly known as the Citizen's Movement, Filimbi, the coalition encourages Congolese youth to peacefully and responsibly perform their civil duties (Yarwood, 2015). Filimbi members and activists organise protests for the release of their members while calling 
on President Kabila to step down. The struggle for change, Lutte pour le Changement (LUCHA) is also gaining prominence in Goma and its environs. Created in June 2012 after the re-election of President Joseph Kabila, LUCHA, which is neither a NGO nor a political party but a coalition of young people, demands among other things social services such as access to portable water, justice against the killing of unarmed civilians in the territory of Beni, reform of the Congolese army, political solutions to the Rwandese refugees in the Congo. In the last two years, it has organised sits-ins, marches, rallies to demand social justice nationwide and respect of the Constitution (Bantariza, HirschelBurns and Schuster, 2017). Even a very young girl, aged 15 joined the protest but she was detained just for holding a card that called for an end to Kabila's rule (Sawyer, 2017).

As far as the ruling party is concerned, a lot of support comes from multinational corporations operating in the mining and forestry industries. The UN High-Level Panel of Experts report (2001) exposed the scramble for Congo's wealth by Multinational Corporations based in Europe, the US, Canada and South Africa (Carroll, 2002). As a result, leaders of resources-rich countries including President Kabila easily become gatekeepers: they collect most of their revenues from taxes on imports and exports, control entry and exit visas, issue licenses that determine who could engage in business activities and many more (Cooper, 2002; Somerville, 2016). The figure below illustrates the vicious circle created by the rent-based power in vogue in most mineral-rich countries: gatekeepers use the proceeds at the gate (rent) to buy the obedience of party officials and key figures within the army, police and other support groups (co-option) while silencing dissident voices (repression) in a sustained effort to remain in power (loss of legitimacy) by force and as long as heaven permits (dictatorship).

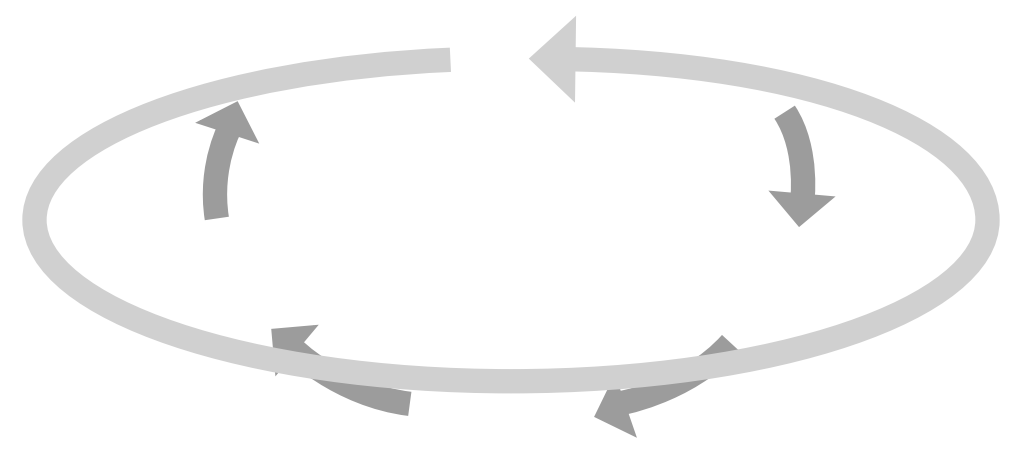

Fig. 1: Rent and Dictatorship nexus

Source: Author

When it comes to the DRC, President Joseph Kabila is not just a gatekeeper who depends on the rent of mining concessions. He is also in charge of companies and guarantor of a primitive capitalist system of exploitation centred on the ownership of private property. 
According to the report by the Congo Research Group at New York University, the Kabila's holdings include over 70,000 hectares of farmland, a lucrative stake in Congo's largest mobile phone network and over 100 mining permits for diamonds and gold (Ross, 2017). The Financial Post presents billionaire mining investor and founder of Ivanhoe Mines Ltd, Robert Friedland as business partner to one of Kabila's brother and Member of Parliament, Zoe Kabila (Wilson, 2017). Some critics argue that "if you want Kabila to pay attention, you have to target the financiers" (Kavanagh, Wilson, \& Franz, 2016).

It is not an overstatement to claim that multinational corporations operating with government-issued mining permits use their economic leverage to not only determine who should lead the DRC but also provide necessary means to shore up the incumbent against all odds. Both the state and foreign companies depend on the cooperation of security agents to protect their assets against disgruntled youths (Brian, 1999). In its recent report, Human Rights Watch made a revelation that the Kabila government hired former Congo's enemies known as M23 rebels stationed in Uganda and Rwanda with special instruction to suppress any threat to the regime (Hancock \& Tilianaki, 2017). In the end, the withdrawal of people's consent by unarmed groups of peoples does not necessarily imply the end of the regime as long as the security agents (military and police force) remain loyal to the ruler. How then can nonviolent activists contribute to the conversion (defection) of the agents of violence? The remainder of the study makes sense of the Civil-Military Relations (CMR) in the light of the Agency theory.

\section{Seeking the conversion of security agents}

The use of legitimate violence is dependent on the government's ability to control the behaviour of the military and the police forces towards unarmed civilian populations. In a repressive system, the distinction between the police and the military is blurred because both seem to have specialised in violence against the citizenry. In the following discussion, we refer to them as security agents. The question as to why the security agents must submit to the whims of the ruler is amply discussed in the literature with regards to the concept of professionalism construed as a voluntary submission of the military to the civilian rule. However, focussing on the classic works of Samuel Huntington's The Soldier and the State: The Theory and Politics of Civil-Military Relations (1957) and Morris Janowitz's The Professional Soldier (1960), it is gathered that a professional soldier in the American context is one that not only submits to the civilian authority but benefits from the autonomy of the military institutions (training, budget, deployment, sacrifice...).

On the one hand however, Huntington lays emphasis on the negative impact of the society's liberal values (democracy, human rights, rule of law) on the soldier and advocates professionalism based on the ideals of conservatism (Nielsen, 2005; Baker, 2007). On the other hand, Janowitz (1960) makes a case for military effectiveness when a soldier 
is able to absorb the liberal values of tolerance, freedom and justice upon which the US democracy is based and knows why he or she must voluntarily submit to the civilian authority in the defence of state. He contends therefore that it is not impossible for the military establishment to resemble a pressure group and as a result, meaningful integration with civilian values (civilianisation) will enhance the civilian control of the military. Others measures that improve the control of the military by the civilians include legislative oversight, extension of control into lower levels of military organizations, and civilian involvement in officer's professional education (Janowitz, 1960 as cited in Nielsen, 2005, p. 67).

Feaver (2003) studies the CMR in the light of the Principal-Agent theory which is widely used in economic analysis and coins the Agency Theory to describe the strategic interactions between the civilian authority (Principal) and the military as servants of the state (Agents). Though both parties are driven by self-interest, namely civilian control and punishment on the one hand and submission and incentives on the other hand, it is possible for a professional soldier to shirk by doing his job of serving the nation without necessarily following the interests of the Principal. Shirking occurs either by omission (failure to carry on instructions from above) or commission (action aimed at undercutting the civilian authority). Simply put, disobedience (shirking) goes against the interests of the principal when the latter loses political control over the security agents and through them, coercive control over the entire population.

Reviewing the above works, Baker (2007), however, points out that the CMR reflects the Cold War thinking which is applicable to the Western democracies that have a long tradition of military professionalism. Given that a military coup is the ultimate form of shirking in which the old agent becomes the new principal, the scholar contends that the Agency theory propounded by Feaver is also relevant to fragile states that are prone to military coups, particularly in sub-Saharan Africa (Baker, 2007). Shirking becomes an option available to a professional soldier or policeman if they come to realise that a popular demand for regime change echoes their own individual aspirations as stakeholders and important members of the society, with family ties, social identities and responsibilities. This seems to be the missing piece of the puzzle in the consent theory of power that puts everybody in one basket as the power base of the ruler.

Accounts of loyalty shifts among security forces as a result of nonviolent campaigns which emphasize the importance of winning over or neutralizing state security forces, along with maintaining nonviolent discipline are well documented (Zunes et al., 2010; Nepstad, 2013). The civilian populations to whom the power to choose their leaders is constitutionally guaranteed have the power to influence the behaviour of security agents that are paid to protect not one single individual but all. In keeping with the focus of this study, the conversion of security agents (defection) requires a new understanding of CMR as opposed to the traditional view in which civilian control is exercised by the 
office of the head of state (commander-in-chief). Galtung (1989, as cited in Zunes et al., 2010) stresses the 'social distance' factor that justifies unsuccessful outcomes of some nonviolent movements: the shorter the distance between contending forces (young protesters and Serbian security forces, Israeli activists and Israeli soldiers, pro-civil rights activists and White police in US), the easier for the resisters to influence their opponents' behavior. The greater the social distance between Black South Africans and Afrikaaner security forces, Palestinians and Israeli troops, local populations and invading foreign troops) the more difficult the struggle. Equally important is the physical distance: the longer the distance between the seat of power (capital) and the peripheries, the less successful the movement which usually begins in remote areas. Therefore the success of the nonviolent struggle depends on the ability of peaceful demonstrators to bridge the gap (distance) and reach out to the security agents with a friendly attitude so as to win them to their laudable cause.

\section{Conclusion}

Nonviolent action works well in developed countries because elected leaders are afraid of being voted out at the next turn of electoral process. This is not the case in most African countries where nonviolent movements often end in chaos as a result of general apathy coupled with tacit endorsement of the regime by external powers. Sharp (2012a: 11) believes strongly in the capacity of the oppressed to liberate themselves and claims that no saviour would come from a foreign land. Using the DRC as case study, the study has argued that the success of nonviolent movements in façade democracies depends on the ability of activists to establish strong ties with security agents. However, one thing is that foreign intervention may support local initiatives for change and another thing is that foreign powers identify with the status quo. In many ways, workers withdraw their human capital and embark on frequent strikes but important allies (security agents, donor countries, multinational corporations and many more) provide the needed support to incumbents in a sustained effort to undermine the consent power of the masses. Findings suggest that submission may work well at the top but it is problematic at the bottom of the pyramid where military men are poorly paid and ill-motivated. They can easily be converted by the message of nonviolent activists. Success in this regard requires that activists of nonviolence endeavour to win the hearts of the security agencies and turn them into partners for change. The possibility of defection or neutrality is already open to the men in uniform as they are allowed to take up courses in peace education, conflict studies and nonviolence in reputable departments of universities around the world. Given that the same consent defines relationships between the ruler and the masses, the principal and the agents, the study recommends that Civil-Military Relations move beyond the elite control of the military and include taxpayers (citizens) in an effort to promote good governance. By bringing the agents of legitimate violence close to the people, the concept of professionalism will take on board the aspirations 
of the masses so that each time the latter decide to descend in the streets and demand political change, they expect the cooperation of their fellow countrymen in uniforms.

\section{References}

1. Atack, I. (2012). Nonviolence in Political Theory. Edinburgh: Edinburgh University Press.

2. Baker, D. (2007). Agency Theory: A New Model of Civil-Military Relations for Africa? African Journal on Conflict Resolution, 7(1), 113-135.

3. Bantariza, R., Hirschel-Burns, T., \& Schuster, S. (2017, May 31). Lucha continua: The youth movement striking fear into Congo's elite. African Arguments. Retrieved from https://africanarguments.org/2017/05/31/lucha-continua-the-youth-movementstriking-fear-into-congos-elite/.

4. Batware, B. (2011, December 5). The role of Multinational Corporations in the Democratic Republic of Congo. Stadtschlaining: European Peace University.

5. Brian, M. (1989). Gene Sharp's Theory of Power: Review Essay. Journal of Peace Research, 26(2), 213-222.

6. Brian, M. (1999). Nonviolence versus Capitalism. Brian Martin. Retrieved from http:// www.bmartin.cc/pubs/99gm.html.

7. Burrowes, R. (1996). The Strategic of Nonviolent Defence: A Gandhian Approach. Albany: State University of New York Press.

8. Carroll, R. (2002, October 22). Multinationals in scramble for Congo's wealth. The Guardian. Retrieved from https://www.theguardian.com/world/2002/oct/22/congo. rorycarroll.

9. Chenoweth, E., \& Cunningham, K. G. (2013). Understanding nonviolent resistance: An Introduction. Journal of Peace Research, 50(3), 271-276.

10. Collier, P., \& Hoeffler, A. (2004). Greed and Grievance in civil war. Oxford Economic Papers, 56(4), 563-596.

11. Collier, P., \& Sambanis, N. (2005). Understanding Civil War: Evidence and Analysis. Washington DC: World Bank.

12. Cooper, F. (2002). Africa since 1940: The past of the present. Cambridge: Cambridge University Press.

13. Cordell, D., Wiese, B. M., Payanzo, N., \& Lemarchand, R. (2018). The Democratic Republic of the Congo. Ecyclopaedia Britannica. Retrieved from https://www.britannica. com/place/Democratic-Republic-of-the-Congo.

14. Danjani, S. (1994). Eyes without Country: Searching for a Palestinian Strategy of Liberation. Philadelphia: Temple University Press.

15. Duffield, M. (2001). Global Governance and the New Wars: The Merging of Development and Security. London: Zed Books.

16. Elworthy, S., \& Hayman, C. (2005). Time to make History as well. In M. Brown (Ed.), You are History: How people make the difference (pp. 163-176). London: Continuum.

17. Evans, G., \& Newnham, J. (1998). Dictionary of International Relations. London: Penguin Books. 
18. Feaver, P. D. (2003). Armed Servants: Agency, Oversight and Civil-Military Relations. Cambridge: Harward University Press.

19. Freedom House. (2015). Democratic Republic of Congo. Freedom House. Retrieved https://freedomhouse.org/report/freedom-world/2015/congo-democratic-republickinshasa.

20. Friedman, T. L. (2006). The World is Flat: The Globalized world in the Twenty-First Century. Penguins Books: London.

21. Galtung, J. (1989). Nonviolence in Israel/Palestine. Honolulu: University of Hawaii, Institute for Peace.

22. Hancock, S., \& Tilianaki, M. (2017, December 4). Interview: How DR Congo's President Hired Rebel Fighters to Crush Protests. Human Rights Watch. Retrieved from https:// www.hrw.org/news/2017/12/04/interview-how-dr-congos-president-hired-rebelfighters-crush-protests.

23. Human Rights Watch. (2017, December 3). "Special Mission": Recruitment of M23 Rebels to Suppress Protests in the Democratic Republic of Congo. Human Rights Watch. Retrieved from https://www.hrw.org/report/2017/12/04/special-mission/recruit ment-m23-rebels-suppress-protests-democratic-republic-congo.

24. Huntington, S. P. (1957). The Soldier and the State: The Theory and Politics of Civil-Military Relations. Cambridge: Harvard University Press.

25. Janowitz, M. (1960). The Professional Soldier: A Social and Political Portrait. New York: Macmillan.

26. Kavanagh, M., Wilson, T., \& Franz, W. (2016, December 15). With his family fortune at stake, Congo President Kabila digs in. Bloomberg. Retrieved from https://www. bloomberg.com/news/features/2016-12-15/with-his-family-fortune-at-stake-congopresident-kabila-digs-in.

27. Korten, D. C. (2001). When Corporations rule the world ( $2^{\text {nd }}$ edition). Connecticut: Kumarian Press.

28. Mbombo, J-M. K. (2008). The UN-EUFOR Cooperation in the South: An appraisal of the Liberal Peace Project in the DRC. Dublin: MPhil Dissertation, Trinity College.

29. Mbombo, J-M. K. (2017). National dialogue as solution to African problems: The D. R. Congo in focus. Academic Journals. Retrieved from http://www.academicjournals.org/ journal/IJPDS/article-abstract/EDFD16566585.

30. Moss, T. J. (2007). African Development: Making sense of the Issues and Actors. London: Lynne Rienner Publishers.

31. Nepstad, S. E. (2013). Mutiny and nonviolence in the Arab Spring: Exploring military defections and loyalty in Egypt, Bahrain and Syria. Journal of Peace Research, 50(3), 337-349.

32. Nielsen, S. C. (2005). Civil-Military Relations Theory and Military Effectiveness. Public Administration and Management, 10(2), 61-84.

33. Nojeim, M. J. (2004). Life and Works of Gandhi and Martin Luther King Jnr: The Power of Nonviolent Resistance. Benin City: Beulahland Publications. 
34. Nzongala-Ntalaja, G. (2015). The Fragile State and Crisis in Eastern Congo. Revue Africaine de la Démocratie et de la Gouvernance, 2(1\&2), 15-37.

35. Pakenham, T. (1991). The Scramble for Africa 1876-1912. London: Abacus.

36. Parekh, B. (1997). Gandhi, A Very Short Introduction. New York: Oxford University Press.

37. Philpot, R. (2005). How the Modern-day Missionaries Called 'Human Rights Activists' Help Wreak Havoc in Africa. In M. P. Brown, You're History: How people make the difference (pp. 95-104). London: Continuum.

38. Powers, R. S., Vogele, W. B., Kruegler, C., \& McCarthy, R. (1997). Protest, Power and Change: An Encyclopedia of Nonviolent Action from ACT-UP to Women's Suffrage. New York: Garland Publishing.

39. Prunier, G. (2009). Africa's World War: Congo, the Rwandan Genocide and the making of a Continental Catastrophe. New York: Oxford University Press.

40. Quinn, C. (2005). Genocide: the Violence and the Silence. In M. P. Brown, You're History: How people make the difference (pp. 235-252). London: Continuum.

41. Ross, A. (2017, July 20). Congo's Kabila and family worth millions, new reports says. Reuters. Retrieved from https://af.reuters.com/article/topNews/idAFKBN1A51KVOZATP.

42. Sawyer, I. (2017, November 17). 15-year-old peaceful Protester Beaten and Detained. Human Rights Watch. Retrieved from https://www.hrw.org/blog-feed/democraticrepublic-congo-crisis.

43. Schell, J. (2004). The Unconquerable World: Why peaceful protest is stronger than war. London: Penguin Books.

44. Schock, K. (2013). The practice and study of civil resistance. Journal of Peace Research, 50(3), 277-290.

45. Sharp, G. (2012a). From Dictatorship to Democracy. London: Serpent's Tail.

46. Sharp, G. (2012b). Sharp's Dictionary of Power and Struggle: Language of Civil Resistance in Conflicts. New York: Oxford University Press.

47. Sharp, G. (1973). The Politics of Nonviolent Action. Boston: Porter Sargent.

48. Sharp, G. (2005). Waging Nonviolent Struggle: 20th Century Practice and 21st Centrury Potential. Boston: Extending Horizons Books.

49. Snow, K. H. (2007, November 3). Congo's President Joseph Kabila: Dynasty or Travesty?. Toward Freedom. Retrieved from https://towardfreedom.org/archives/africaarchives/congos-president-joseph-kabila-dynasty-or-travesty/.

50. Sobek, D., \& Clare, J. (2013). Me, myself and allies: Understanding the external sources of power. Journal of Peace Research, 50(4), 469-478.

51. Somerville, K. (2016, October 20). Keeping it Family : How Africa's Corrupt Leaders Stay in Power. Global Geneva. Retrieved from http://www.global-geneva.com/keepingit-family-how-africas-corrupt-leaders-stay-in-power/

52. United Nations Development Programme. (2015). Human Development Reports: Democratic Republic of the Congo. UNDP. Retrieved from http://www.hdr.undp.org/en/ countries/profiles/COD. 
53. Wilson, T. (2017, July 20). Ivanhoe's Congo success follows deals with ties to the government. Financial Post. Retrieved from https://business.financialpost.com/commod ities/ivanhoes-congo-success-follows-deals-with-kabilas-brother-1.

54. Worldbank. (2015). Democratic Republic of Congo: Overview. World Bank. Retrieved from https://www.worldbank.org/en/country/drc/overview.

55. Yarwood, J. (2015, March 16). What are you scared of Joseph Kabila? Senegalese, Burkinabe and Congolese Activists arrested in DRC. Africa is A Country. Retrieved from https://africasacountry.com/2015/03/yen-a-marre-and-le-balai-citoyen-activistsarrested-in-drc.

56. Zunes, S., Merriman, H., \& Stephan, M. J. (2010). Nonviolent Struggle. In R.A. Denemark and R. Marlin-Bennett (Eds.), The International Studies Encyclopedia. Hoboken: WileyBlackwell.

57. Zunes, S., L. R. Kurtz and S. B. Asher. (1999). Nonviolent Social Movements: A geographical perspective. Massachusetts: Blackwell Publishers. 